\title{
Re-Shaping the Faculty: Emergence and Development of "Permanent-Contingent" Roles through the Lens of Cultural-Historical Activity Theory
}

\author{
Oleksandr Tkachenko ${ }^{1} \&$ Karen Seashore Louis ${ }^{1}$ \\ ${ }^{1}$ Department of Organizational Leadership, Policy, and Development, University of Minnesota, USA \\ Correspondence: Karen Seashore Louis, Professor, 206 Burton Hall, 178 Pillsbury Dr. SE, Department of \\ Organizational Leadership, Policy, and Development, University of Minnesota, USA. Tel: 1-612-626-8971
}

Received: November 3, 2016

Accepted: December 5, 2016

Online Published: December 7, 2016

doi:10.5430/ijhe.v6n1p140

URL: http://dx.doi.org/10.5430/ijhe.v6n1p140

\begin{abstract}
This study retrospectively examines the emergence and development of a new class of full-time non-tenure track employees in a large land grant research university in the U.S., which created the employment category in 1980 . We employ cultural-historical activity theory (CHAT) to explore how this class of employees became institutionalized within the university organizational structure and within the university's consultative and decision-making processes. The study advances the understanding of how broad academic personnel strategies emerge in higher education. Given that there are few longitudinal studies examining the way personnel strategies are made in higher education, we hope that this paper will provide a useful frame of reference for developing research on institutions of higher education as work environments. By utilizing CHAT in a higher education setting, our inquiry also contributes an alternative perspective to the stream of research on organizational change in higher education.
\end{abstract}

Keywords: Activity theory, CHAT, Contingent, Non-tenure-track, Faculty, Personnel strategies, Higher education

The past few decades have exposed increasing concern about the changing composition of the faculty at major universities. In the 1960s and 70s, "regular" faculty were the dominant "professional workers" in major institutions, but the 1980s and onward saw the proliferation of contingent faculty that were often part-time (AAUP, 2003; Cowley, 2010; Gottschalk \& McEachern, 2010). While the academic community in many countries has agonized over part-time under-employed faculty (Kimber, 2003; Anderson, 2007), less attention has been paid to those who occupy non-"regular" but full-time permanent positions. To address this gap, this paper addresses the following question: How does the expansion of a new class of full-time "faculty-like" employees occur in large, public universities?

Our investigation employs an archeological ethnography method (Engeström, Kerosuo, \& Kajamaa, 2007) using archival documents, organizational artifacts, and narrated memories to explore how this group of employees became legitimated within a single university's organizational structure over 40 years. Using cultural-historical activity theory (CHAT) as an interpretive lens, this paper examines key contradictions that underpinned the process of institutionalization and explores the dialectics of this process. The study advances the understanding of how broad personnel strategies emerge in higher education. Given that there are few longitudinal studies examining personnel policies in this context, we anticipate providing a frame for developing research on higher education as a work environment.

\section{Overview}

Non-traditional contingent faculty positions within higher education have increased rapidly over the last decades. In 1963, full-time appointments "off the tenure track" (which, in the U.S., confers significant job security) comprised about 3.3\% of all full-time faculty positions (AAUP, 2003); by the late 1980s, Rosenblum and Rosenblum (1990) concluded that part-time and non-tenure track (NTT) faculty provided "a substantial portion of all undergraduate instruction" (p. 157). Full-time appointments outside the traditional faculty system constitute a majority of all faculty members (Gappa, Austin, \& Trice, 2007). Although controversial, the increase in contingent or non-permanent faculty positions is observed in an increasing number of European and Australian universities (Finkelstein, 2010; Kimber, 2003; Ryan, Burgess, Connell, \& Groen, 2013). 
Some see this long-term trend as a consequence of changing labor supply (Carter, 1971). Universities have failed to address the predicted overproduction of Ph.Ds, which leads to lower wages, career disruptions, and limited need for institutions to offer full-time tenured appointment (Stephan, 2013). At the same time, a growing number of women receive the doctorate as they enter child-bearing years, which is assumed to lead to preferences for less demanding non-tenure-track positions (Wolfinger, Mason, \& Goulden, 2009). Others suggest that internal conditions are the cause: constrained budgets and the need to meet fluctuating student demands make non-permanent employees attractive (Wyatt-Nichol, 2007). This micro-economic perspective is countered by a study that found similar personnel patterns at elite (private and public) universities, which have large endowments and well-publicized initiatives to increase the number of highly qualified full professors (Cross \& Goldenberg, 2009). Instead, some argue that the neoliberal zeitgeist affects university decisions, privileging employer flexibility over workers' rights in higher education as in other sectors (Slaughter \& Rhoades, 2004).

Irrespective of cause, personnel changes confront universities with clear challenges: (1) recruiting and retaining high quality personnel for non-traditional appointments; (2) finding a balance between different types of appointments to ensure the quality of teaching; and (3) establishing a culture that appropriately rewards personnel for their contributions. In many cases, universities are blamed for insufficient attention to adapting to the predicted oversupply of faculty members, which leads to lower wages, career disruptions, and limited need for institutions of education to offer full-time tenured appointment (Stephan, 2013). As Kezar (2013) points out, multiple models for "managing" these challenges are developing, but what these will look like in the future is still unclear. Empirical work that addresses managing a differentiated internal labor market and workforce on campus is beginning to emerge in several countries (Kezar, 2012; Davis, Perrott, \& Perry, 2014). There are, however, only a few investigations of the expansion of the non-tenured track employees at the organizational level (see Hollenshead et al., 2007).

\section{Research Focus}

This study contributes to an understanding of the changing nature of faculty work by providing a detailed overview of the development and institutionalization of the full-time/contingent personnel category with teaching functions in a single university. The focal institution is a large public research university (the $\mathrm{U}$ ) whose mission, like its peers, is threefold: research and discovery; teaching and learning; outreach and public service. Like similar institutions, research and knowledge production tend to be privileged, and it is among the top in the U.S. as measured by research funding. The $\mathrm{U}$ is governed by a Board of Regents, whose members are elected by the state legislature but it is rarely subjected to pressure from elected officials. Other than routine legislative complaints about administrative bloat, personnel issues are viewed as an internal matter.

At present, the U's employment system comprises six employee groups: (a) tenured and tenure-track (TTT) faculty with permanent contracts; (b) professional and administrative staff (P\&A); (c) civil service; (d) union-represented staff; (e) graduate assistants; and (d) students. The employee category under investigation (NTT) is a subcategory of the $\mathrm{P} \& \mathrm{~A}$ class that is primarily engaged in delivering instruction in credit-bearing courses.

In 2016, full-time staff classified as "Academic P\&A" with teaching functions (approximately 950) considerably outnumbered part-time contingent faculty (under 300) (Appendix 1). At present, the majority of the NTT employees with teaching functions hold annually renewable appointments, but many have been working at the $\mathrm{U}$ for decades (see Baldwin et al., 1993). The compensation plan for "faculty-like" NTT employees is separate from the tenured/tenure track/TTT faculty, but they share retirement and other benefits. They are represented in all 26 of the university-wide faculty consultative committees, including the committee on Academic Freedom and Tenure. P\&A employees (all categories) also have 25 representatives at the Faculty Senate, along with 168 TTT faculty members (including the President). In other words, by policy they have been largely integrated in the university's consultative governance structure, which exercises considerable influence over most administrative decisions (Lehmberg \& Pflaum, 2001). Nevertheless, their position remains ambiguous, as we document below.

\section{Method and Data Sources}

Once we formulated the problem (after conducting preliminary interviews with NTT/P\&A employees and examining existing documents on the P\&A class), we employed the archaeological ethnography method (Engeström et al., 2007). The method combined research of archival documents, organizational artifacts, and interviews from administrators and faculty/employee representatives who participated in the key events (see below). Specifically, data collection included the following procedures:

1) Review of the all-university administrative "briefs" (since 1975). This step resulted in an extensive list of 'news-worthy items' that were related to the P\&A issue; 
2) Review of faculty governance minutes (since 1975) with regard to the issues pertinent to the P\&A class. (Note 1)

3) Search of digital university archives by entering key words given the findings from steps 1 and 2.

4) Locating and interviewing faculty (TTT and NTT) and administrators whose names were identified in key documents for the purposes of clarifying and triangulating interpretations. (Note 2)

This approach resulted in a large number of documents and events for review from which we first created an extensive timeline of events and then an abbreviated timeline of "critical incidents" that were covered in multiple data sources. We interviewed key participants who were involved in those decision-making processes and asked them to interpret and elaborate the timeline. In some instances, the participants' responses led to further archival research, including older ad hoc committee reports or university policy documents (See Appendix 2) and additional interviews.

\section{Timeline: Changes in the Faculty at "The U"}

In this section, we elaborate on the events that illustrate: (1) manifestations of key contradictions emerging as the NTT class developed; and (2) practices aimed at resolving contradictions and ambiguity. Table 1 contains the abbreviated history of the P\&A employee group, which includes NTT and administrative staff. Events that denote institutionalization of the new faculty class are indicated in italics.

Table 1. Abbreviated History of the P\&A Employee Group

\begin{tabular}{ll}
\hline Year & Event \\
\hline$\approx 1975$ & $\begin{array}{l}\text { The idea of a new category of professional and administrative staff is raised in university } \\
\text { discussions. }\end{array}$ \\
& $\begin{array}{l}\text { A personnel category of academic professional and administrative }(P \& A) \text { staff is established by } \\
\text { Regents policy }\end{array}$
\end{tabular}

1981 An Academic Staff Advisory Committee (ASAC) is appointed by the president to advise him on P\&A needs and concerns

1983 Eleven P\&A employees sign a lawsuit (Rajender petition) claiming gender inequity in pay and promotion among faculty.

1984 The Campus Assembly (largest faculty governance body) votes to include P\&As as part of the faculty component of the governance system.

1991 Significant revision of P\&A policies and procedures.

$2000 \quad$ Administrative policy on academic appointments requires units to file a personnel plan if total contingent instructors exceeds $25 \%$.

2002 Academic Staff Advisory Committee (ASAC) becomes Council of Academic Professionals and Administrators (CAPA).

2005 Regents vote to approve new U senate structure which includes 23 elected P\&A staff members.

2009 CAPA commissions a subcommittee to consider changing CAPA to a P\&A Senate.

2011 CAPA becomes the P\&A Senate; its Executive Committee becomes the P\&A Consultative 2014 Committee (name change parallels the Faculty Senate and Faculty Consultative Committee).

"Job Families" initiative reclassifies P\&A, further differentiating teaching from administrative staff.

4.1 Establishing the P\&A Class (mid 1970s - 1980)

In the $1970 \mathrm{~s}$, there were two personnel categories at the $\mathrm{U}$ : faculty and civil service. By the middle of the decade, it was apparent that these did not accommodate several trends. First, more large-scale research came with increasingly complicated federal requirements; legal mandates, such as affirmative action, required more oversight; new federal programs allowed expanded outreach opportunities throughout the state. The faculty could no longer manage the increasing tasks that were traditionally part of their work. At the same time, the advanced professional skills required by these jobs did not fit the civil service code. Senior administrators, such as the University's chief financial officer, were neither faculty nor civil service, but they had received tenured professorships because there was no alternative employment category. Several colleges were hiring temporary faculty-physicians, engineers and architects-to 
work on grants, using one-year appointments. They too did not fit the "tenured faculty" model, which was also becoming more structured according to a report by the Chair of the Faculty Consultative Committee.

Reductions in state appropriations highlighted the contradictions. Given uncertain finances, conferring tenure status (life-time appointments) on career administrators was not seen as wise. The emerging group of contingent research staff required more appropriate personnel policies (e.g., advance notice on reappointments). By 1975, a new employee classification, academic professionals and administrators, was raised as a possible solution, and was finalized in policy in mid-December, 1980, by the Board of Regents. According to the policy, the P\&A group constituted two categories of employees:

1) Professional personnel whose appointments paralleled regular faculty. These employees were not supposed to perform full-time teaching and scholarly work as faculty, but were "assigned to duties enhancing the research, teaching, and service functions of the University."

2) Administrative personnel who were envisioned to be involved in policy development and implementation, or in coordinating and supervising activities of the University.

The intention was that matters related to P\&A benefits, pay, and raises were to be covered by the same policies that applied to the faculty. The policy specified four types of P\&A appointments: annual, fixed term, probationary, and continuous. Probationary and continuous appointments were parallel to tenure-track and indefinite tenure appointments available to faculty.

As of 1980, the P\&A category comprised 214 employees; that number was not expected to rise significantly according to the author of the recommendations.

\section{2 "Extremely broad and diverse" (1981 - 1991)}

After establishing the category, several important events shaped the process of the P\&A institutionalization. On June 1, 1981, the Academic Staff Advisory Committee (ASAC) met for the first time, legitimating the group as part of the consultative process. Two years later, eleven NTT employees signed a petition claiming that the policy and practice of the University disproportionately assigned female employees to the P\&A category, where promotion opportunities and academic freedom protection were limited. In addition, within five years it was clear that the P\&A class had far outgrown initial expectations.

A university-wide committee appointed to investigate found no conclusive evidence for sex discrimination, and determined that it was often "appropriate" to have a larger proportion of females working in NTT positions. The report pointed, however, to "the neglected state of affairs of the University's human resources management practices relevant to the P\&A category" (Rajender P\&A Committee Report, 1985, p. 5). As evidence, they noted that:

- $\quad$ P\&A employees numbered over 1,000, many of whom were teaching.

- Only 46 (4\% of those eligible) had attained continuous appointment, and only 66 were in a probationary track appointment, although promotion tracks were part of the policy.

The inclusion of $\mathrm{P} \& \mathrm{~A}$ employees as part of the faculty governance system (which occurred through a faculty vote in 1984) made it difficult to ignore the ad hoc committee report, which was followed in 1987 by a faculty-initiated Special Senate Committee that investigated the use of the Academic Professional Classification. This revealed "an extremely broad and diverse category of employees," with most having annual appointments. According to the committee, some units of the $U$ engaged in "a deliberate policy to avoid making probationary or continuous appointments" regardless of the permanence of funding.

It also concluded that the existing P\&A Manual, unlike the faculty-authored tenure code, appeared to be written by administrators. It was recommended to review the manual and consult the P\&A community in the process of its revision. In sum, the report embraced the enhancement of "faculty like" $P \& A$ appointments. The new and revised P\&A Policies and Procedures were issued on October 15, 1990, and approved by the ASAC in June 1991. It did not address another of the report's concerns: whether having a single personnel class (P\&A) was suitable given the distinction between purely administrative and "faculty like" work.

\section{3 "Putting the House in Order" (1992 - 2001)}

The archives reveal regular state funding cutbacks during this period, with budget cuts and tuition increases prominent in policy discussions. With the potential threat of job insecurity, personnel and employment issues became an ancillary agenda of numerous discussions and forums that took place in the 1990s. 
The U was increasingly fueled by research grants. A 1992 university "Brief' reported that employees supported by non-state funds had grown by $40 \%$, while state-funded employment had grown only by $10 \%$. The financial situation demanded austerity measures, including closing programs, which generated passionate discussions about proposed staff reductions and pay plans. According to archival documents, each employee group (faculty, civil service, P\&A employees) perceived itself as 'disadvantaged' and proposed initiatives to bring salaries to market level.

In 1998, the U's new budget model, "Responsibility Centered Management" put more revenue into units in return for increased responsibility for generating funds and covering their costs. Under the new framework, $100 \%$ of tuition revenue and $51 \%$ of the overhead generated on research grants money went directly to the colleges. The change was "dramatic" (U "Brief," April 15, 1998), in part because salaries were no longer funded by "central administration" alone.

In addition, two new personnel trends emerged. One concerned the conversion of civil service appointments (considered secure) to the P\&A category (annual/shorter term). Initial conversions in the early 1990s were by individual choice, but most new job openings to perform the same or similar duties were posted as P\&A. There was no central oversight over these conversion decisions, which occurred within the appointing unit.

The second trend concerned growth in "faculty-like" appointments. The latter received the Faculty Senate's full attention only in 1998, with the report of its Academic Appointments Subcommittee, "Putting the House in Order." During its investigation, the committee found "the proliferation of uncounted faculty-like appointments," whose numbers were "ascertainable only locally" because most personnel practices were managed within units. The committee reported that these employees taught, did research and scholarship, and performed service "just as though they were faculty," and often acted in place of the faculty, "but officially, by University policy, they are not counted as faculty." According to the subcommittee, between 1987 and 1997, the TTT appointments decreased by 11.8\% while the P\&A faculty-like appointments rose by $28.4 \%$.

The report called for a better treatment for the P\&A class rather than a wholesale change in HR policies, and several initiatives were introduced in the following years. Professional development leaves (sabbaticals) for P\&A staff were approved in 2000. An administrative policy on academic appointments (2001) provided a more consistent structure for hiring and reviewing five categories of personnel who provided instruction. Promotional ladders were established for the Professional Academic personnel: those with a Master's degree might be promoted to senior teaching specialists; lecturers (who had a Ph.D.) might be promoted to senior lecturers.

The report also recommended that oversight of instruction was to remain primarily with TTT faculty. Each college was to develop a personnel plan that would articulate how appointment options would ensure the academic quality of its programs, including specifics for any unit in which non-TTT positions exceeded $25 \%$. Faculty governance approval was required, and plans were to be regularly reviewed. Meeting summaries also reveal discussions about transforming the presidentially appointed Academic Staff Advisory Committee (ASAC) into a more representative body for P\&A employees, including a formal constitution and bylaws.

\subsection{Institutionalizing a Changed Faculty (2002 - Present)}

Over the last decade, two trends emerged. First, representative bodies for the P\&A class rapidly became more visible in university governance. In February 2002, the ASAC became the Council of Academic Professionals and Administrators (CAPA), which was defined as an elected body representing colleges, administrative units, and campuses. A few years later, in 2005, the Board of Regents approved a new governance structure recommended by faculty and staff: the U Senate now includes 25 elected P\&A staff and 25 elected civil service staff members. In 2009-10, a CAPA subcommittee recommended changing CAPA to the P\&A Senate, which was adopted and implemented in July, 2011. This did not separate the P\&A class from the faculty governance system, but it acknowledged a formal, parallel governance structure that is, on paper, co-equal to the Faculty and Student Senates.

Second, yet again the U's job classification system came under scrutiny. A 2005 strategic initiative to raise the institution's international ranking was linked to a review of human capital goals. In 2006, the Vice-president for Human Resources convened working groups to propose ways to make the employee classification and compensation systems more effective. The P\&A working group (2008) reported that they appreciated the independence, autonomy, and flexibility in their positions, but saw their classification and compensation system as poorly-defined, poorly-understood, and unstructured. The report proposed placing P\&A employees with teaching functions under "Education, Instructional Services, and Teaching" in a new "job family." The Job Classification System redesign that began in 2012 was completed in 2014, but implementation was held up in some colleges by changes in the U personnel software (minutes of the P\&A Board, CLA, December 18, 2014) and has been further challenged by an 
effort to unionize faculty. This latter effort has created new incentives for NTT faculty to become eligible to vote by becoming part of the same job classification at TTT faculty (minutes of the P\&A Board, CLA, December 18, 2014), a move that is contested by the administration (VP memo, March 17). In sum, revisions that affect the nearly 1,000 NTT employees who are part of this "family" are ongoing.

\section{Summary}

The event analysis suggests that a large research university may experience significant internal contradictions as it attempts to "manage" changes that affect a core function: teaching. Incremental change took place, but these actions did not aim to resolve the underlying contradictions (as discussed below). Flurries of activity were followed by adjustments in a stable system that was premised on a clear division of labor (traditionally between "faculty" and everyone else) and based on strong norms, including academic freedom and a focus on inquiry. In the end, without deliberate decisions at any level, the composition of "the faculty" and their employment conditions had changed radically. Why did this occur?

\subsection{CHAT as an Interpretive Framework}

Cultural-historical activity theory (CHAT) is built on the work of developmental psychologists who explored how individuals interact with the wider cultural and historical context in which they are engaged (Vygotsky, 1978; Leont'ev, 1978). Engeström $(1987,2001)$ extended this foundation by including a "community" element and thus shifting an analytic focus from an activity of an individual to a collective activity system. In Vygotsky's (1978) work, tools and signs - products of human life (aka instruments) - were seen as an important element to mediate the relationship between the subject (individual) and the object (motive). Engeström $(1987,2001)$ further built on this idea and proposed "norms/rules" to mediate the relationship between the subject and the community, and "division of labor" to mediate the relationship between the community and the object. In addition, Engeström $(1987,2001)$ offered a graphic model of an activity system consisting of seven elements: subject, object, community, instruments, division of labor, rules, and outcome (see Figure 1). All seven elements are deeply interconnected and mutually defining (as illustrated by the arrows in Figure 1). If, previously, the subject was seen as an individual, in the contemporary CHAT, the subject can be seen as an individual, but also as a work unit or an organization (Blackler, 2009). CHAT has been widely used for modeling human activities and specifically for examining and facilitating organizational change (Blackler, 2009; Engeström \& Sannino, 2011; Sannino, Engeström, \& Lemos, 2016).

Several important assumptions define CHAT, including:

- Object-orientation: activity systems are open, dynamic, and oriented towards objects of human activities. The object is "the why" of an activity (Miettinen, Samra-Fredericks, \& Yanow, 2009). Objects of human activities are socially constructed, emergent, and contested. "The object is more than just goal or product. Objects are durable concerns and carriers of motives; they are generators and foci of attention, volition, effort, and meaning" (Engeström, 2015, p. xvi).

- Multi-voicedness: activity systems contain multiple actors who bring different perspectives.

- Historicity: activity systems change and develop over time. Their disturbances, problems, and potentials need to be understood against the background of their own histories.

- Contradictions are the main source of change and development of activity systems. Contradictions are historically accumulating structural tensions that take place both within and beyond activity systems (Engeström, 2001).

- Transformation potential: activity systems move through long cycles of transformation.

Together these create a dynamic framework that is applicable to both formal and informal processes in groups, and that supports a sociological approach to studying collective learning within structured social relationships (Young, 2008). 


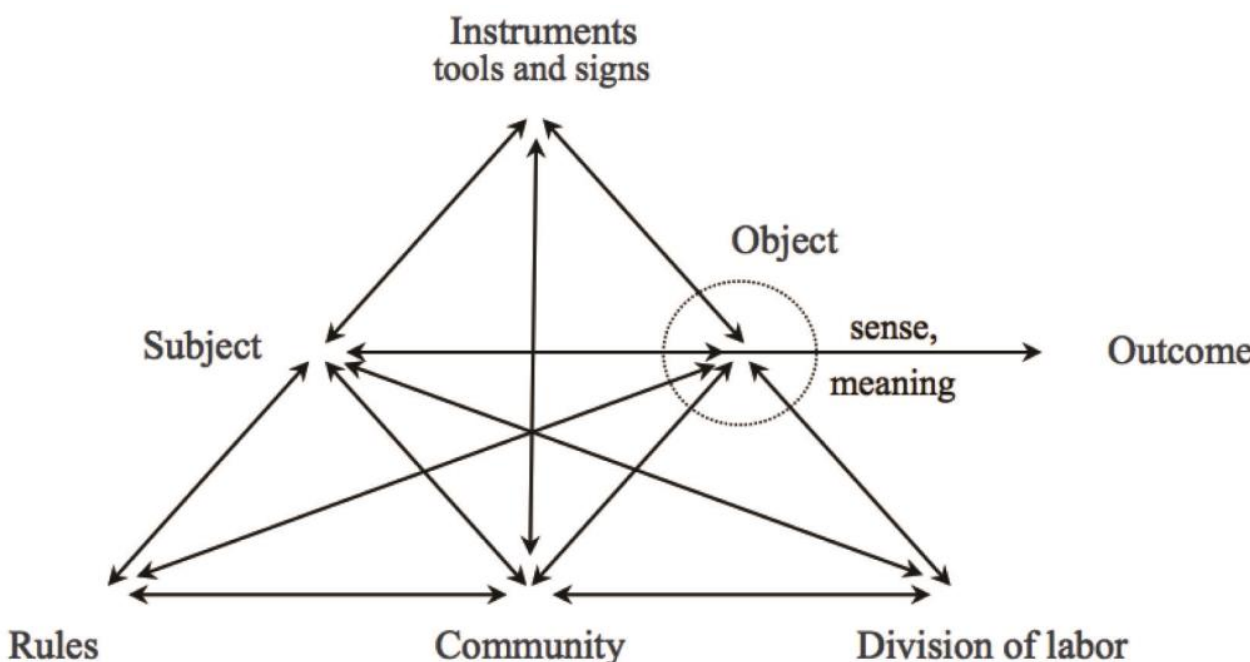

Figure 1. The structure of a human activity system (Engeström, 2001)

Engeström (1987) emphasized the dynamic nature of contradictions as a stimulus for change. These can occur (a) within each element in the activity system (primary contradictions); (b) between some elements in the system (secondary contradictions), such as when the rules become outdated and hamper the efforts towards an emergent/new object; (c) between the old (fading) and new (emerging) system when a transition is taking place (tertiary contradictions); and also (d) between the given activity system and adjacent activity systems (quaternary contradictions). When modeling human activities, contradictions are typically illustrated in the form of lightning (to render the idea of tensions and disturbances in the system) (See Figure 2 as an example). Given the assumptions summarized above, we saw a strong rationale for utilizing CHAT as a framework for interpreting the formal and informal events observed at the $\mathrm{U}$.

Like most large universities, the $\mathrm{U}$ activity system is oriented towards its research/teaching/service mission [the object], and its complex activity system comprises many actors and units [subjects] that are "loosely coupled" (Weick, 1976). College- and department-level activity systems are semi-autonomous within a larger (university-wide) system, in large measure because "the work" varies widely between units that range from a large medical school to a small department of Asian Languages and Literature. Under such "loose" arrangements, subjects often "share the same broad object, [but] ... their cultural and historical expectations about the same object may be quite different and even in contradiction with each other" (Jarzabkowski, 2010, p. 135). Nevertheless, we observed system change and paid attention to the role of contradictions related to the evolution of the P\&A class of employees across units. Figure 2 below depicts main primary and secondary contradictions that became evident in our analysis.

\section{Instrument}

\section{"faculty-like" \& administrators}

Secondary Contradictions as conjoined category

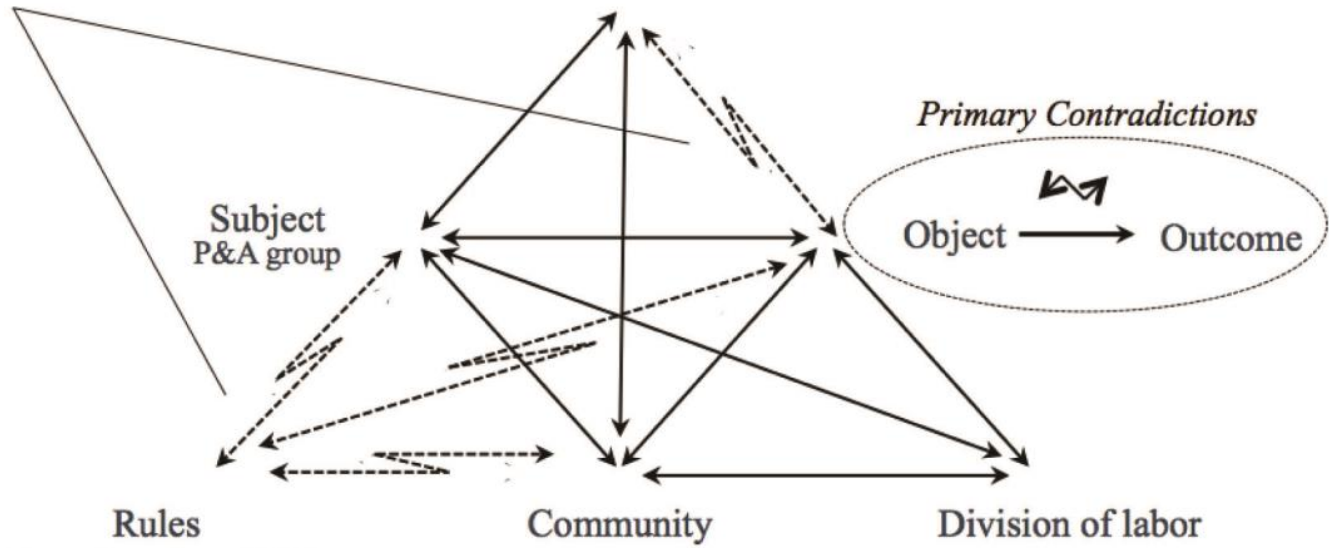

Regent's policy of 1980

Figure 2. Primary and secondary contradictions in the U activity system 


\subsection{Primary Contradictions: the Object of the U activity System}

In the 1970s, changes in the institutional environment aggravated [primary] contradictions within the U object/mission. The P\&A employee group was initiated as an instrument aimed at mediating the relationships between several groups (faculty, civil service, Board of Regents) and the emergent object [mission], due to (a) increases in the scope of funded research activities, (b) demand for instructors-practitioners in expanding professional schools, and (c) new administrative demands that distracted faculty from their main work.

The sub-categories initially identified in the P\&A group were explicitly tied to the U's mission: e.g., Academic Professional employees were to be "engaged in teaching, research, and service" (Regent's Policy, 1980) while the Academic Administrative group was charged with supporting all three missions' components. The establishment of the new personnel groups brought a short-term balance to the activity system, while acknowledging the importance of all three elements of the mission.

\subsection{Secondary Contradictions: Instrument - Object}

Conjoining academic professionals and administrators in a single employment classification [instrument] - a creative solution in 1980 - resulted in new tensions. As the P\&A employee group mushroomed beyond the original intent, the $\mathrm{U}$ found it extremely difficult to manage the differences of their employment conditions and performance expectations, which ranged from the University's top lawyer to skilled lab technicians in the Medical School. As noted by Jarzabkowski (2010), "mediators are not neutral but have historical and cultural baggage that can both constrain and enable action and interaction" (p. 133). From this perspective, the U administrators struggled to deal with the "baggage" for the entire reviewed time period. The most recent emerging instrument - the job family classification initiative of 2013-14 - also attempts to mediate this on-going issue, but it is already clear that it will not be a resolution.

\subsection{Secondary Contradictions: Subject-Community}

Tensions quickly arose between the P\&A group [subject] and other employee groups [community]. Promises of "faculty-like" treatment of the individual P\&A employees (Regent's policy of 1980) were unfulfilled, and issues of gender discrimination were manifest. The Rajender report, which deemed the concentration of women in the P\&A class reasonable but their working conditions discriminatory, is a clear manifestation of these contradictions, and the underlying issues have remained controversial in subsequent efforts to examine gender and employment class salary inequities. "Regular" tenured faculty have been ambivalent, sometimes embracing P\&A colleagues (supporting their inclusion in governance committees) and sometimes not (authoring reports that expressed concerns about the growth of the class and requesting that they be excluded from voting on a faculty union).

Throughout the reviewed history, minor adjustments of policies [rules] were introduced to mediate the relationships between the P\&A group and the larger community, when individuals raised issues of equity and fairness. Adjustments were in most cases incremental and surface-level (inclusion in governance and committees) rather than comprehensive, and have not, according to current reports that lie outside our historical analysis, "solved" the equity issues between P\&A and faculty.

\subsection{Tertiary Contradictions: The Emergent Mode vs the Fading Mode of Activity}

Our findings suggest that perspectives on the U's mission differed between academic units (colleges and departments) due to their cultural and historical expectations. This led to official conformity (every college used the P\&A category and involved P\&A staff in governance activities) but significant variations in implementation of the intent of policy. This is illustrated by the differences that report after report revealed in how colleges employed the new instrument: the P\&A employee category. In some colleges (Business) the number of P\&A "faculty-like" instructional employees grew rapidly, others (e.g., Medical School) relied on other types of instructional personnel ("courtesy appointments") that were not part of the P\&A policy. Furthermore, the work that P\&A instructional staff performed varied widely. In some professional colleges (College of Education and Human Development) they taught and advised doctoral students; in others (Business) their work included undergraduate and master's instruction, while in Liberal Arts they provided only undergraduate instruction. 


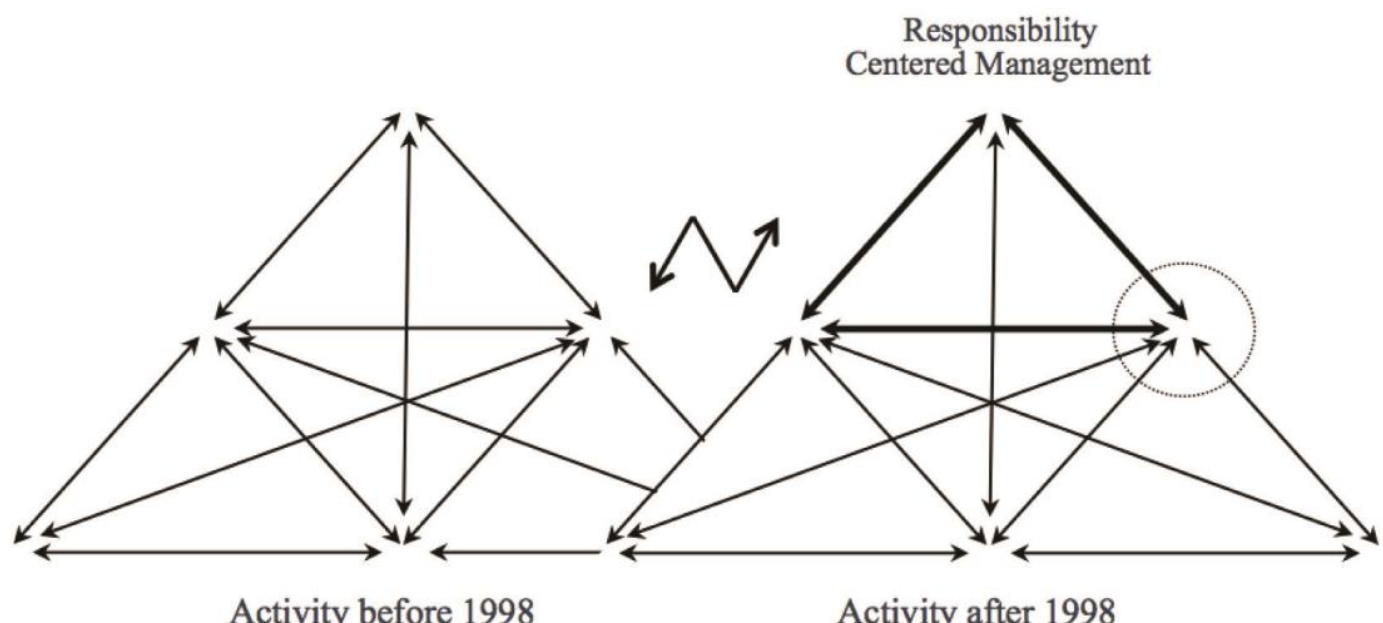

Figure 3. Tertiary contradictions in the U activity system

In 1998, a new university financial framework, "Responsibility Centered Management," [instrument] was established to facilitate the transition between the old (fading) and emergent new modes of activity, where externally-funded research was of increasing importance (See Figure 3). The framework strengthened units' autonomy and reinforced decentralized hiring practices that led to even greater growth of the P\&A instructional class. By making colleges fully responsible for funding both newly created and vacated positions, the role of the $\mathrm{U}$ in providing oversight and monitoring of job descriptions and classifications was further eroded. In turn, the subsequent policy [instrument], requiring units to file a personnel plan if P\&A instructors exceeded $25 \%$ aimed to preserve remnants of the "old" TTT faculty-dominant system that was historically and culturally rooted in the activity system. There is no evidence, however, that this policy changed the continued growth of the class of NTT, permanent teaching faculty which now comprises almost $1 / 3$ of the instructional staff. The institutionalization of personnel policies affecting the composition of the faculty and "faculty-like" employee categories led to further tensions between the colleges'/departments' distinctive approach to meeting the teaching/research/service object and University-wide efforts to develop a consensus about the future of a $21^{\text {st }}$ century University - in which, historically, faculty played the major role.

The tensions that continue to arise and aggregate are still largely representative of the tertiary contradiction between the emerging mode and (fading yet still) present mode of the activity system that is "protected" by the 1981 state law, which says that "the $[\mathrm{U}]$ faculty positions....are governed by the University's Tenure Code, a definition that has existed since the law was adopted and that reflects the unique role of the faculty at the University in carrying out its three-part mission of teaching, research, and engagement" (memo from VP for Human Resources, March 24, 2016). Thus, we see that internal contradictions in personnel policies that we highlighted above, which rarely receive external publicity, are being joined by contradictions between the emerging system at the $U$ and other adjacent systems (i.e., the quaternary contradictions that are beyond the scope of this paper's focus).

\section{Conclusion and Discussion}

Our findings suggest that the status of P\&A employees whose primary function is delivering instruction has been changing largely through decisions that involved "muddling through" rather than as a response to immediate economic pressures, other events, or a "neoliberal zeitgeist." The application of a CHAT perspective suggests that muddling through occurred primarily because a large and diverse institution, such as the U, did not have the capacity to identify and address emerging tensions as they arose, and was consistently faced with multiple and accumulated tensions of a larger scale that prevented "getting the horse back into the barn."

The growth of the permanent "faculty-like" class of employees vastly outpaced the use of adjunct temporary or part-time substitutes for regular tenured/tenure track faculty. Because they were permanent and integrated into faculty functions, they were gradually accepted by most faculty as "like us." The trajectory of inclusion means that they have formal roles in the University Senate on all major committees and were incorporated at the university level. Adding the new class has not undermined the traditional role of faculty consultation and representation, but has (if anything) created a larger constituency to balance increasing external regulation and internal administrative oversight. 
Examining the data through the CHAT lenses indicates that, while the initial stimulus was administrative (the need to appoint people with advanced degrees to NTT positions), the evolution of the role was affected by:

- Decentralized decision-making that allowed professional personnel decisions to be made at department/program levels;

- A desire on the part of people in the new class and the faculty they worked with directly to "make sense" of their role in the university, which led to a gradual emergence of new communities within units;

- The absence of significant events that would create conflict over the growth of the role.

Thus, unlike previous studies that emphasize institutional transformation resulting from sequenced, planned or connected events (Kezar \& Eckel, 2002), or responses to external pressures and demands (Hashem, 2007), we find that the development of a permanent "faculty-like" class was less consequence of strategy than of incremental personnel policies to solve immediate problems. In agreement with Kezar and Eckel (2002), however, our findings also suggest that a collective process of making meaning out of uncertain and ambiguous situations (Weick, 1995) is important in navigating change in universities, particularly with respect to changes in the faculty role.

The CHAT framework seems particularly useful as a mechanism for examining the evolution of institutional trends and policies in higher education for several reasons. First, as shown in this paper, many policies emerge as a consequence of multiple linked decisions over a long period of time. The historicity of institutional policy is, in our view, underrepresented in studies of higher education institutions. Second, the focus on institutional culture, which is perhaps best revealed by examining the discourse that is present in multiple documents, may reveal important differences as well as similarities among institutions that share a common classification (in this case, a large research-intensive university). Examining activity, as represented in the discussions that occur before policies are finalized, is a particularly important feature of CHAT, because it draws attention to the micro-politics and interests that underpin the way in which "loosely coupled" organizations, like universities, maintain some consistency while allowing flexibility to meet new challenges and goals that may vary.

The study examines what occurred in only a single institution. While the inquiry provides a thorough account of the events that shaped the emergence and development of the new personnel category, the findings may not be generalizable to other institutions. We suspect that the incorporation of full-time, permanent non-tenured faculty may be a model that works in larger, research-intensive universities, where even in times of financial constraint there tend to be more varied sources of funding and therefore more personnel flexibility. As Kezar (2013) points out, other models (such as employing an ever-larger part-time adjunct faculty) may be better suited to unionized, tuition-driven institutions such as two-year colleges. MA granting public universities (or technical universities that focus on professional degrees) may find the "clinical professor" model a different approach in which part-time appointments are attractive to both the institution and instructors who remain employed in their field (Clinebell \& Clinebell, 2008; Datar, Garvin \& Cullen, 2011). In areas such as nursing, where there is a persistent shortage of qualified tenure-track faculty, clinical appointments may be the only solution (Allan \& Aldebron, 2008; Shipman \& Hooten, 2008).

Future investigations that include other similar institutions should address the degree to which a "faculty-like" employment category represents the development of a permanent but second-class status within the university, or meets the needs of both individuals and the institution for more flexibility in employment. Exploring whether a particular model employed at different types of institutions provide more optimal (satisfactory) solutions in meeting the needs of both individuals and the institutions could also yield important practical and theoretical insights.

In sum, we offer this analysis not as a policy directive that should shape the way in which universities think about personnel management. Rather, it provides a cautionary observation about the way in which decisions that are made to solve temporary inconsistencies or perceived anomalies in large higher education settings may accumulate in ways that could not have been anticipated. Once set in motion, any solution that changes the composition of the faculty may engender a shift in institutional activity systems that presents its own unmanageable future scenario.

\section{References}

Allan, J. D., \& Aldebron, J. (2008). A systematic assessment of strategies to address the nursing faculty shortage, U.S. Nursing Outlook, 56(6), 286-297. https://doi.org/10.1016/j.outlook.2008.09.006

American Association of University Professors [AAUP] (2003). Policy statement on contingent appointments and the academic profession. Retrieved from http://www.aaup.org/report/contingent-appointments-and-academic-profession. 
Anderson, V. (2007). Contingent and marginalised? Academic development and part-time teachers. International Journal for Academic Development, 12(2), 111-121. https://doi.org/10.1080/13601440701604914

Baldwin, R. G., Chronister, J. L., Rivera, A. E., \& Bailey, T. G. (1993). Destination unknown: An exploratory study of full-time faculty off the tenure track. Research in Higher Education, 34(6), 747-761. https://doi.org/10.1007/BF00992158

Blackler, F. (2009). Cultural-historical activity theory and organization studies. In A. Sannino, H. Daniels, \& K.D. Gutiérrez (Eds.), Learning and expanding with activity theory (pp. 19-39). Cambridge, UK: Cambridge University Press. https://doi.org/10.1017/CBO9780511809989.003

Carter, A.M. (1971). Scientific manpower for 1970-1985. Science, 172, 132-140. https://doi.org/10.1126/science.172.3979.132

Clinebell, S. K., \& Clinebell, J. M. (2008). The tension in business education between academic rigor and real-world relevance: The role of executive professors. Academy of Management Learning \& Education, 7(1), 99-107. https://doi.org/10.5465/AMLE.2008.31413867

Cowley, J. (2010). Confronting the reality of casualisation in Australia: Recognising difference and embracing sessional staff in law schools. Queensland University of Technology Law and Justice Journal, 10(1), 27-43. Retrieved from http://ssrn.com/abstract=1702635

Cross, J. \& Goldenberg, E. (2009). Off-track profs: Nontenured teachers in higher education. Cambridge, MA: MIT Press.

Datar, S. M., Garvin, D. A., \& Cullen, P. G. (2011). Rethinking the MBA: Business education at a crossroads. Journal of Management Development, 30(5), 451-462. https://doi.org/10.1108/02621711111132966

Davis, D., Perrott, B., \& Perry, L. (2014). Insights into the working experience of casual academics and their immediate supervisors. Australian Bulletin of Labour, 40(1), 46-67. Retrieved from http://EconPapers.repec.org/RePEc:fli:journl:35022

Engeström, Y. (1987). Learning by Expanding: An activity-theoretical approach to developmental research. Helsinki: Orienta-Konsultit.

Engeström, Y. (2001). Expansive learning at work: toward and activity theoretical reconceptualization. Journal of Education and Work, 14(1), 133-156. https://doi.org/10.1080/13639080020028747

Engeström, Y. (2015). Learning by expanding: An activity-theoretical approach to developmental research (2nd ed.). New York: Cambridge University Press.

Engeström, Y., \& Sannino, A. (2011). Discursive manifestations of contradictions in organizational change efforts: A methodological framework. Journal of Organizational Change Management,24(3), 368-387. https://doi.org/10.1108/09534811111132758

Engeström, Y., Kerosuo, H., \& Kajamaa, A. (2007). Beyond discontinuity: Expansive organisational learning remembered. Management Learning, 38(3), 319-336. https://doi.org/10.1177/1350507607079032

Finkelstein, M.J. (2010). Diversification in the academic workforce: The case of the US and implications for Europe. European Review, 18(S1), S141-S156. https://doi.org/10.1017/S1062798709990366

Gappa, J.M., Austin, A.E., \& Trice, A.G. (2007). Rethinking Faculty Work: Higher Education's Strategic Imperative. San Francisco, CA: Jossey-Bass.

Gottschalk, L., \& McEachern, S. (2010). The frustrated career: Casual employment in higher education. Australian Universities' Review, 52(1), 37-50. Retrieved from http://eric.ed.gov/?id=EJ877046

Hashem, M. (2007). Becoming an independent field: Societal pressures, state, and professions. Higher Education, 54(2), 181-205. https://doi.org/10.1007/s10734-005-2295-5

Hollenshead, C., Waltman, J., August, L., Miller, J., Smith, G., \& Bell, A. (2007). Making the best of both worlds: Findings from a national institution-level survey on non-tenure-track faculty. Ann Arbor, MI: Center for the Education of Women.

Jarzabkowski, P. (2010). An activity-theory approach to strategy as practice. In D. Golsorkhi, L. Rouleau, D. Seidl, \& E. Vaara (Eds.) Cambridge Handbook of Strategy as Practice (pp. 127-140). Cambridge, UK: Cambridge University Press. https://doi.org/10.1017/CBO9780511777882.009 
Kezar, A. (2013). Changing faculty workforce models. New York: TIAA-Cref Institute. Retrieved November 27, 2016.

Kezar, A. (Ed.). (2012). Embracing non-tenure track faculty: Changing campuses for the new faculty majority. New York, NY: Routledge.

Kezar, A., \& Eckel, P. (2002). Examining the institutional transformation process: The importance of sensemaking, interrelated strategies, and balance. Research in Higher Education, 43(3), 295-328. https://doi.org/10.1023/A:1014889001242

Kimber, M. (2003). The Tenured 'Core' and the Tenuous 'Periphery': The casualisation of academic work in Australian universities. Journal of Higher Education Policy and Management, 25(1), 41-50. https://doi.org/10.1080/13600800305738

Lehmberg, S., \& Pflaum, A.M. (2001). The University of Minnesota, 1945-2000. Minneapolis, MN: University of Minnesota Press.

Leont'ev, A. N. (1978). Activity, consciousness, and personality. Englewood Cliffs, N.J.: Prentice-Hall.

Miettinen, R., Samra-Fredericks, D., \& Yanow, D. (2009). Re-turn to practice: An introductory essay. Organization Studies, 30(12), 1309-1327. https://doi.org/10.1177/0170840609349860

Rosenblum, G. \& Rosenblum, B.R. (1990). Segmented labor markets in institutions of higher learning. Sociology of Education, 63(3), 151-164. https://doi.org/10.2307/2112834

Ryan, S., Burgess, J., Connell, J., \& Groen, E. (2013). Casual academic staff in an Australian university: Marginalised and excluded. Tertiary Education and Management, 19(2), 161-175. https://doi.org/10.1080/13583883.2013.783617

Sannino, A., Engeström, Y., \& Lemos, M. (2016). Formative interventions for expansive learning and transformative agency. Journal of the Learning Sciences, 25(4), 599-633. https://doi.org/10.1080/10508406.2016.1204547

Shipman, D., \& Hooten, J. (2008). Without enough nurse educators there will be a continual decline in RNs and the quality of nursing care: contending with the faculty shortage. Nurse Education Today, 28(5), 521-523. https://doi.org/10.1016/j.nedt.2008.03.001

Slaughter, S., \& Rhoades, G. (2004). Academic capitalism and the new economy: Markets, state, and higher education. Baltimore, MD: The Johns Hopkins University Press.

Stephan, P. (2013). How to exploit postdocs. BioScience, 63(4), 245-246. https://doi.org/10.1525/bio.2013.63.4.2

Vygotsky, L.S. (1978). Mind in society: the development of higher psychological processes. Cambridge, MA: Harvard University Press.

Weick, K. (1976). Educational organizations as loosely coupled systems. Administrative Science Quarterly, 21(1), 1-19. https://doi.org/10.2307/2391875

Weick, K.E. (1995). Sensemaking in organizations. Thousand Oaks, CA: SAGE Publications.

Wolfinger, N.H., Mason, M.A., \& Goulden, M. (2009). Stay in the game: Gender, family formation and alternative trajectories in the academic life course. Social Forces, 87(3), 1591-1621. https://doi.org/10.1353/sof.0.0182

Wyatt-Nichol, H. (2007). Job perceptions of contingent and traditional faculty. Academic Exchange Quarterly, 11(2), 164-171.

Young, M. (2008). Bringing knowledge back in: From social constructivism to social realism in the sociology of education. Milton Park, OX: Routledge.

\section{Notes}

Note 1. It is worth noting that the governance system at the $U$ is unusually well-documented: Meeting minutes typically include detailed quotes, including names, as well as summaries. We acknowledge the role of Dr. Gary Engstrand, whose role in reporting governance meetings provided the largest data source for this analysis.

Note 2. Because many of this study's key events occurred 25-30 years ago, only a few active participants could be located. Our primary data source is the historical archive. 


\section{Appendix 1}

\section{Appointment Categories with Teaching Function}

According to the $\mathrm{U}$ administrative policy on academic appointments, there are five categories of personnel that deliver instruction in courses for credit:

1. Regular (Tenured and Tenure-Track) Faculty:

Members of the tenured and tenure-track faculty.

2. Term (Non Tenure-Track) Faculty:

2A. Contract Faculty. Members of the faculty on annual, renewable, or multi-year contracts.

2B. Temporary Faculty. Members appointed to address temporary needs of 1-2 years.

2C. Visiting Faculty. Faculty at other universities who are temporarily here.

3. Adjunct Faculty:

3A. Adjunct Faculty from Within the University. Persons who hold regular or term (contract or temporary) faculty status in one main department and who are appointed by a second department or college.

3B. Adjunct Faculty from Outside the University. Professionals in the community who offer instruction on an occasional, part-time basis.

4. Academic Staff:

4A. Academic Professional Staff who hold primary responsibility for teaching.

4B. Academic Professional or Administrative Staff with primary non-instructional duties who assume part-time instructional duties.

5. Graduate Teaching Assistants

Appendix 2

\section{List of the Key U's Policy Documents and Ad Hoc Committee Reports Used in the Analysis (in a Chronological Order)}

1. Koffler-Ibele's memorandum on regulations concerning faculty tenure (November, 1975);

2. Regent's Policy on P\&A class (1980);

3. Rajender P\&A Committee Report (November, 1985);

4. Academic Professional and Administrative Staff Policies and Procedures - 'Blue Book manual,' (September, 1985, \& November, 1986, revisions);

5. Report of the Special Senate Committee on the use of the Academic Professional Classification (October, 1987);

6. Academic Professional and Administrative Staff Policies and Procedures (June, 1991);

7. Putting the House in Order: a report of the Joint Committee on Academic Appointments to the Faculty Senate (November, 1998);

8. Administrative policy on academic appointments with teaching functions (2001);

9. Recommendations of the Civil Service and P\&A Classification and Compensation Working Groups 'Retaining and attracting talent: The future of U of M employees,'(April, 2008);

10. Faculty Consultative Committee, Metrics and Measurements Subcommittee Report, (September, 2008). 